\title{
Kegiatan Penyuluhan dan Pemeriksaan Kesehatan untuk Membiasakan PHBS bagi Warga Desa Kemantren
}

\author{
Imam Rofiki ${ }^{*}$, Siti Roziah Ria Famuji ${ }^{2}$ \\ 1,2Universitas Islam Negeri Maulana Malik Ibrahim Malang \\ email: $\underline{\text { imam.rofiki@uin-malang.ac.id¹․riafamuji@gmail.com² }}{ }^{2}$
}

\begin{abstract}
Efforts to familiarize clean and healthy life is significant to improve the degree of public health. The strategies for familiarize clean and healthy living behaviors are counseling and checking of clean and healthy life behavior. The purpose of these activities was to increase knowledge, awareness, and potential of clean and healthy life behavior in Kemantren Village, Malang. This dedication involved the participation of the people of Kemantren Village so that the community could realize that health improvement can be started from healthy daily living habits. The method used was counseling, and health checking. The results of the service showed that the community gave a positive response and was very enthusiastic in participating in health education and counseling activities.
\end{abstract}

Keywords: Counseling, health check, clean and health

\begin{abstract}
Abstrak
Upaya untuk membiasakan hidup bersih dan sehat sangat penting untuk meningkatkan derajat kesehatan masyarakat. Beberapa strategi yang dapat dilakukan untuk membiasakan perilaku hidup bersih dan sehat adalah memberikan penyuluhan serta pemeriksaan perilaku hidup bersih dan sehat. Tujuan dari kegiatan ini adalah untuk meningkatkan pengetahuan, kesadaran dan potensi pola perilaku hidup bersih dan sehat bagi warga Desa Kemantren, Malang. Kegiatan ini melibatkan partisipasi masyarakat Desa Kemantren sehingga masyarakat dapat menyadari bahwa peningkatan kesehatan dapat dimulai dari kebiasaan hidup sehat seharihari. Metode yang digunakan adalah penyuluhan dan pemeriksaan kesehatan. Hasil pengabdian ini menunjukkan bahwa masyarakat memberikan respon positif dan sangat antusias dalam berpartisipasi dalam pendidikan kesehatan dan konseling.
\end{abstract}

Kata Kunci: Penyuluhan, pemeriksaan kesehatan, hidup bersih dan sehat

\section{PENDAHULUAN}

Hidup sehat merupakan salah satu unsur penting dalam upaya untuk meningkatkan Indeks Pembangunan Indonesia yang ditentukan oleh kondisi lingkungan dan perilaku masyarakat. Upaya untuk mengubah perilaku masyarakat untuk meningkatkan derajat kesehatan dapat melalui program Perilaku Hidup Bersih dan Sehat (PHBS) (Baker, Morawska, \& Mitchell, 2019; Broyles, Gollub, Tohme, \& Katzmarzyk, 2020; Saputro, 2017). PHBS merupakan sekumpulan perilaku yang dipraktikkan atas dasar kesadaran sebagai hasil pembelajaran yang menjadikan seseorang, keluarga, kelompok atau masyarakat mampu menolong dirinya sendiri di bidang kesehatan dan berperan aktif dalam mewujudkan kesehatan masyarakat (Kemenkes RI, 2011). Mengingat kesehatan merupakan hal yang penting bagi manusia supaya dapat berkonsentrasi dalam bekerja dan beraktivitas sehari-hari (Fletcher, Landolfo, Niebauer, Ozemek, Arena, \& Lavie, 2018; Khoiruddin, Kirnantoro, \& Sutanta, 2015; König, Matt, Kortgen, Turnbull, \& Hartog, 2019; Park \& Kwan, 2017).

PHBS memiliki tujuan untuk memberikan pengalaman belajar bagi perorangan, kelompok, keluarga dan masyarakat dengan membuka jalur komunikasi, informasi dan edukasi untuk meningkatkan pengetahuan, sikap dan perilaku sehingga masyarakat sadar, mau dan mampu mempraktikkan PHBS melalui pendekatan pimpinan (advocacy), bina suasana (social support), dan pemberdayaan masyarakat (empowerment) (Depkes RI, 2002). Menurut Kemenkes RI (2016), terdapat sepuluh indikator PHBS yang dapat dijadikan acuan untuk menilai keberhasilan dari praktik PHBS pada tingkatan rumah tangga, yaitu: (1) persalinan yang ditolong 
tenaga kesehatan, (2) pemberian ASI eksklusif, (3) penimbangan bayi dan balita secara berkala, (4) cuci tangan menggunakan sabun dan air bersih, (5) penggunaan air bersih, (6) penggunaan jamban yang sehat, (7) pemberantasan jentik nyamuk, (8) konsumsi buah dan sayur, (9) aktivitas fisik setiap hari, dan (10) tidak merokok di dalam rumah. Hal ini sangat penting untuk diperhatikan karena banyak kasus morbiditas dan mortalitas disebabkan oleh rendahnya tingkat pengetahuan pada masyarakat (Jayadipraja, Prasetya, Azlimin, \& Mando, 2018).

Peningkatan pengetahuan dapat dilakukan dengan melakukan penyuluhan, yang mana kegiatan penyuluhan merupakan suatu proses komunikasi dua arah antara komunikator (penyuluh) dan komunikan dalam suatu interaksi. Penyuluhan sangat ditentukan oleh bentuk hubungan antar komunikator dengan sasaran yaitu masyarakat, jika diantaranya telah terjadi penyesuaian, komunikasi akan berjalan lancar. Dalam hal ini komunikator harus mencoba mencapai kesesuaian dengan komunikan, dimana sesuatu yang disampaikan juga harus merupakan arti yang diterima komunikan (Kaddi, 2014).

Pembiasaan hidup bersih dan sehat sangat penting untuk semua usia mulai dari neonatus hingga lansia. Semakin dini pembiasaan hidup sehat dilakukan, semakin tinggi pula derajat kesehatan masyarakat karena upaya preventif tersebut. Neonatus yang sakit atau dengan gizi buruk berisiko tinggi terhadap kegagalan pertumbuhan dan perkembangan (Ramel, Brown, \& Georgieff, 2014). Kesehatan pada anak usia sekolah juga dapat mempengaruhi hasil belajar sehingga anak akan berprestasi di sekolah dan melakukan kegiatan sosial dengan baik (Fatimawati, 2017). Pada remaja (usia 11-20 tahun) juga sangat penting, sebab usia ini merupakan periode pematangan organ reproduksi. Selain itu juga perlu diperhatikan kesejahteraan fisik, mental serta sosial secara utuh di masa pubertas (Sulistyaningtyas, Tamtomo, \& Suryani, 2016). Pada tingkat dewasa hingga lansia pembiasaan hidup sehat juga tidak kalah penting. Terlebih penuaan dan penyakit degeneratif merupakan tantangan besar bagi individu ataupun keluarga dalam sistem sosial, ekonomi dan kesehatan (Lunenfeld \& Stratton, 2013).

Desa Kemantren terdapat di Kecamatan Jabung wilayah Kabupaten Malang. Fasilitas kesehatan di Desa Kemantren yaitu terdapat satu puskesmas Jabung dan satu penanggung jawab bidan untuk Desa Kemantren. Namun, untuk jasa dokter masih kurang, sebab dokter tidak selalu ada di puskesmas. Kesadaran warga Desa Kemantren untuk berobat ke pelayanan kesehatan juga kurang. Mayoritas warga berobat jika gejala penyakit sudah parah. Hal ini terjadi karena kurangnya pengetahuan warga tentang hidup sehat. Oleh karena itu, diperlukan penyuluhan tentang perilaku hidup bersih dan sehat (PHBS) sebagai upaya preventif dan menambah kewaspadaan terhadap gejala-gejala penyakit.

Penyuluhan dan pemeriksaan kesehatan menjadi program utama dalam kegiatan pengabdian kepada masyarakat yang dilakukan oleh mahasiswa Universitas Islam Negeri Maulana Malik Ibrahim Malang. Kehidupan masyarakat Desa Kemantren sangat terasa kekeluargaannya, sering diadakan perkumpulan atau majelis untuk orang dewasa dan lansia. Anak-anak di sana juga banyak dan bermain berkelompok. Hal tersebut memudahkan kami untuk mengumpulkan massa dan memberikan penyuluhan. Kegiatan ini memberikan informasi perilaku hidup bersih dan sehat (PHBS) serta praktiknya untuk warga Desa Kemantren. Kontribusi pengabdian ini diharapkan masyarakat Desa Kemantren dapat memahami pentingnya perilaku hidup bersih dan sehat agar dapat menumbuhkan kesadaran akan pentingnya pola hidup sehat guna meningkatkan kualitas hidup menjadi lebih baik.

\section{METODE}

Kegiatan pengabdian ini dilaksanakan oleh 15 mahasiswa Universitas Islam Negeri Maulana Malik Ibrahim Malang bersama dosen pendamping lapangan. Mahasiswa yang terlibat terdiri atas 11 perempuan dan 4 laki-laki. Sasaran pengabdian adalah warga Desa Kemantren, Kecamatan Jabung, Kabupaten Malang. Waktu pelaksanaan pengabdian dilakukan selama 1 bulan. 
Pelaksanaan kegiatan pengabdian masyarakat untuk membiasakan hidup bersih dan sehat pada warga Desa Kemantren ini dilakukan dengan beberapa tahap. Pertama, persiapan identifikasi masalah pada 5-6 Juli 2019 dengan cara menggali informasi dari ketua RW tentang masalah kesehatan yang sering terjadi serta kerjasama untuk penyampaian informasi dan pengumpulan massa. Tahap kedua yaitu sosialisai, berupa penyuluhan akan pentingnya hidup sehat guna meningkatkan kesadaran masyarakat. Ketiga, tahap pemeriksaan kesehatan, dan keempat tahap contoh praktik PHBS. Tabel 1 berikut menunjukkan agenda penyuluhan dan praktik PHBS yang telah dilaksanakan di Desa Kemantren. Kegiatan ini berlangsung mulai tanggal 9 Juli 2019 hingga 4 Agustus 2019.

Tabel 1. Agenda penyuluhan dan praktik PHBS di Desa Kemantren

\begin{tabular}{|c|c|c|}
\hline No. & Program Kegiatan & Tempat \\
\hline 1. & $\begin{array}{l}\text { Penyuluhan ibu hamil, senam hamil dan skrining HIV/AIDS } \\
\text { bersama Ibu Bidan }\end{array}$ & Gedung PKK \\
\hline 2. & Posyandu balita bersama Ibu Bidan & Rumah Ibu Suhartini \\
\hline 3. & $\begin{array}{l}\text { Penyuluhan tentang Bahaya Rokok, Penyuluhan dan Praktik } \\
\text { tentang Cara Mencuci Tangan dan Gosok Gigi yang Baik dan } \\
\text { Benar }\end{array}$ & Rumah Ibu Wasiati \\
\hline 4. & $\begin{array}{l}\text { Penyuluhan kesehatan pada Pusat Informasi dan Konseling } \\
\text { Remaja (PIK-R) SMA Sunan Kali Jaga dan praktik penggunaan } \\
\text { sphygmomanometer }\end{array}$ & SMA Sunan Kali Jaga \\
\hline 5. & $\begin{array}{l}\text { Pemeriksaan tekanan darah, gula darah, kolesterol, asam urat } \\
\text { serta Komunikasi Informasi Edukasi } \\
\text { pemeriksaan tersebut }\end{array}$ & $\begin{array}{l}\text { Rumah Ibu Wasiati } \\
\text { dan door to door }\end{array}$ \\
\hline
\end{tabular}

Selanjutnya, pada tanggal 5 Agustus 2019 tahap evaluasi dilakukan oleh mahasiswa dan dosen pendamping lapangan bersama Bapak Kepala Desa Kemantren dan Bapak Rukun Warga (RW). Dalam hal ini dilakukan pembahasan tentang perkembangan dari pengetahuan kesehatan Warga Kemantren dan memotivasi mitra untuk tetap menerapkan perilaku hidup bersih dan sehat dalam kehidupan sehari-hari guna meningkatkan kualitas hidup supaya lebih sehat.

1. Penyuluhan Kesehatan

a. Penyuluhan Kehamilan

Penyuluhan tentang kehamilan ini dilakukan bersama dengan ibu bidan penanggungjawab Desa Kemantren. Kegiatan ini meliputi penyuluhan kesehatan ibu hamil, pelatiahn senam ibu hamil serta skrining HIV/AIDS yang bertempat di Gedung PKK. Antusias ibu-ibu hamil di Desa Kemantren sangat baik dalam mengikuti penyuluhan dan senam hamil. Sembari skrining HIV/AIDS, ibu hamil juga dapat periksa tekanan darah dan konsultasi langsung dengan ibu bidan.

b. Penyuluhan Kesehatan Anak

Sasaran dari penyuluhan ini adalah anak-anak usia sekolah TK dan SD yang mengikuti bimbingan belajar gubuk baca 87 di Desa Kemantren. Metode yang digunakan merupakan metode yang dapat menarik perhatian anak-anak, yaitu dengan menonton video dan bernyanyi bersama sambal mempraktikkan materi kesehatan. Materi yang dipilih adalah mencuci tangan dan gosok gigi dengan baik dan benar, serta penyuluhan tentang bahaya merokok. Selain itu juga ada pemberian hadiah bagi anak-anak yang dapat menjawab soal di akhir penyuluhan. Selanjutnya follow up dilakukan setiap ice breaking bimbingan belajar dengan recall langkah-langkah cuci tangan serta gosok gigi dengan baik dan benar.

c. Penyuluhan Kesehatan Remaja

Sasaran dari penyuluhan ini adalah adik-adik siswa SMA Sunan Kali Jaga, khususnya yang mengikuti organisasi PIK-R (Pusat Informasi dan Konseling Remaja). Penyuluhan ini ditekankan untuk PIK-R dengan tujuan untuk membentuk kader kesehatan, supaya dapat lebih efektif dan selanjutnya bisa dilakukan sharing teman sebaya oleh kader-kader tersebut. Adapun materi yang disampaikan merupakan materi yang diminati siswa siswi SMA Sunan 
Kali Jaga dan disampaikan melalui LCD berupa power point dan video edukasi. Kemudian dilakukan post test dan pembagian hadiah untuk adik-adik yang paling cepat menjawab pertanyaan terkait materi yang disampaikan.

2. Pemeriksaan Kesehatan

a. Posyandu Balita

Kegiatan posyandu balita meliputi penimbangan berat badan, tinggi badan atau panjang badan, imunisasi dan juga edukasi terkait hasil pengukuran tersebut. Hasil pengukuran kemudian ditulis di buku kesehatan ibu dan anak. Lalu dianalisis apakah bayi atau balita tersebut memiliki pertumbuhan yang sesuai dengan usianya atau mengalami keterlambatan pertumbuhan dan perkembangan. Kemudian dilakukan KIE pada ibu anak.

b. Pemeriksaan Tekanan Darah

Pemeriksaan tekanan darah diberlakukan kepada usia dewasa dan lansia mengingat resiko tekanan darah tinggi meningkat seiring bertambahnya usia. Pengukuran tekanan darah dilakukan menggunakan manual ataupun digital sphygmomanometer. Pemeriksaan ini dilakukan di posko kesehatan dan juga door to door ke rumah warga khususnya lansia yang tidak bisa datang ke posko kesehatan. Setelah pengukuran, hasil dikategorikan pada nilai normal atau abnormal yang selanjutnya dilakukan edukasi kepada warga terkait hasil tersebut.

c. Pemeriksaan Gula Darah, Kolesterol dan Asam Urat

Kegiatan ini dilakukan di posko kesehatan dan juga door to door ke rumah warga dengan sasaran usia dewasa hingga lansia. Pengukuran gula darah, kolesterol dan asam urat dilakukan menggunakan point of care testing (POCT), yang mana darah warga diambil sedikit kemudian diukur pada suatu alat hingga hasil pengukuran muncul. Kemudian hasil tersebut dikategorikan pada nilai normal atau abnormal yang selanjutnya dilakukan edukasi kepada warga terkait hasil tersebut.

\section{HASIL DAN PEMBAHASAN}

Kegiatan pengabdian masyarakat Desa Kemantren ini melibatkan seluruh usia, mulai neonatus sejak dalam kandungan, anak-anak, remaja, dewasa hingga lansia. Pelaksanaan kegiatan meliputi penyuluhan kesehatan, praktik secara langsung terkait beberapa indikator perilaku hidup bersih dan sehat di tatanan rumah tangga, pemeriksaan tekanan darah, gula darah, kolesterol, asam urat serta Komunikasi Informasi Edukasi (KIE) dari hasil pemeriksaan tersebut. Berikut adalah dokumentasi kegiatan selama pelaksanaan pengabdian.

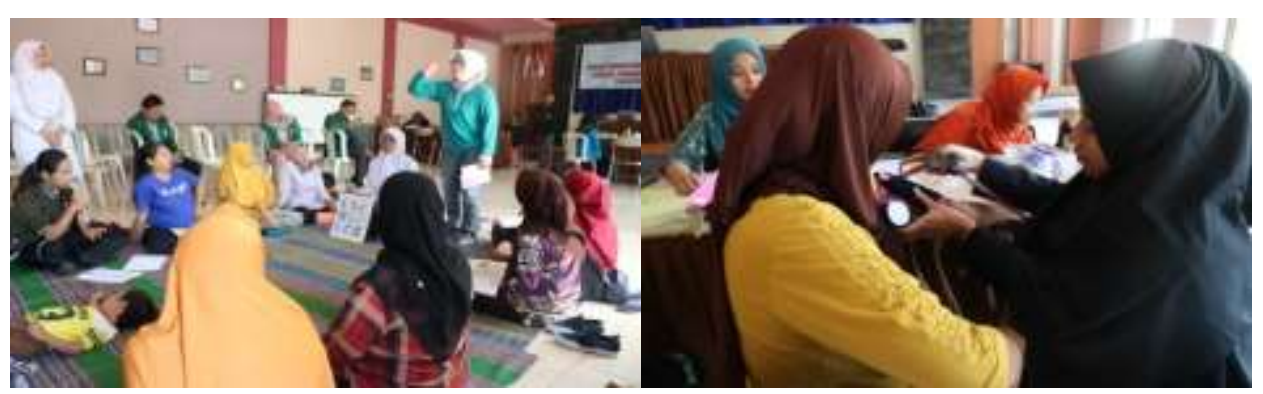

Gambar 1. Penyuluhan kehamilan, senam hamil dan skrining HIV/AIDS

Penyuluhan dan skrining HIV/AIDS untuk ibu hamil ini dilakukan oleh yang lebih berpengalaman, yaitu dengan Ibu Bidan penanggung jawab Desa Kemantren. Penyuluhan dan senam ibu hamil untuk menjaga kesehatan dan kebugaran ibu hamil dan menambah pengetahuan tentang apa-apa yang sebaiknya dan tidak seharusnya dilakukan ketika hamil. Skrining HIV/AIDS bertujuan untuk deteksi dini dan penanganan segera apabila ditemukan HIV/AIDS. Hal ini sesuai dengan indikator PHBS nomor 1 yakni persalinan dibantu oleh tenaga kesehatan dengan standar penggunaan alat-alat yang bersih, steril serta aman untuk mencegah infeksi dan risiko bagi keselamatan ibu dan bayi. Dan juga sesuai dengan indikator PHBS Nomor 2 yaitu pemberian ASI eksklusif khususnya untuk bayi yang berusia 0-6 bulan. 


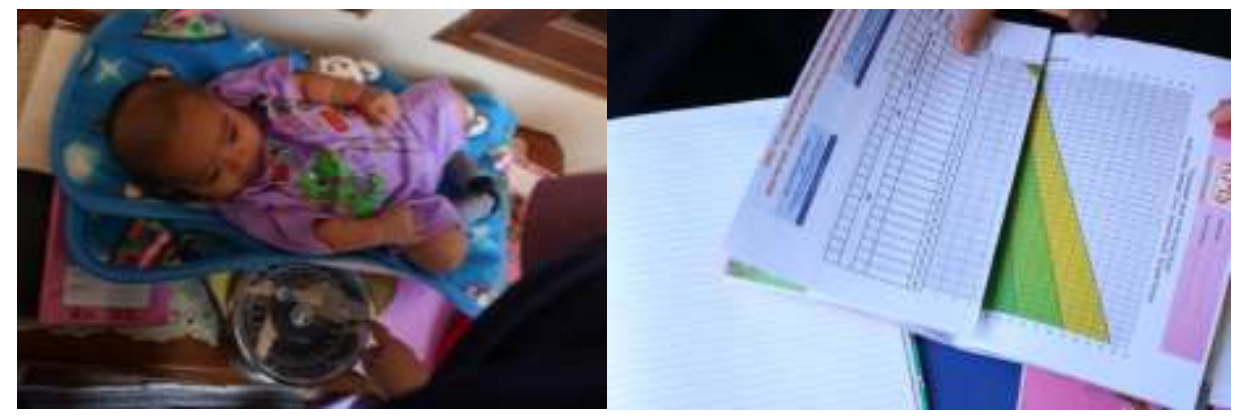

Gambar 2. Posyandu balita

Posyandu balita dilakukan untuk mengetahui pertumbuhan serta perkembangan balita di Desa Kemantren meliputi pengukuran berat badan, tinggi badan atau panjang badan, imunisasi serta penyuluhan terkait kesehatan ibu dan balita. Hal ini sesuai dengan indikator PHBS nomor 3, yakni untuk menimbang bayi dan balita secara berkala untuk mengurangi risiko kekurangan gizi keterlambatan pertumbuhan, stunting dan lain sebagainya. Dan apabila ditemukan kelainan tersebut, supaya dapat dilakukan pencegahan sedini mungkin untuk mengatasinya. Dari hasil pengukuran yang telah dilakukan, bayi dan balita di Desa Kemantren tergolong memiliki pertumbuhan dan perkembangan yang normal, walaupun tidak sedikit juga yang mengalami penurunan berat badan namun masih tergolong normal sesuai dengan usianya.

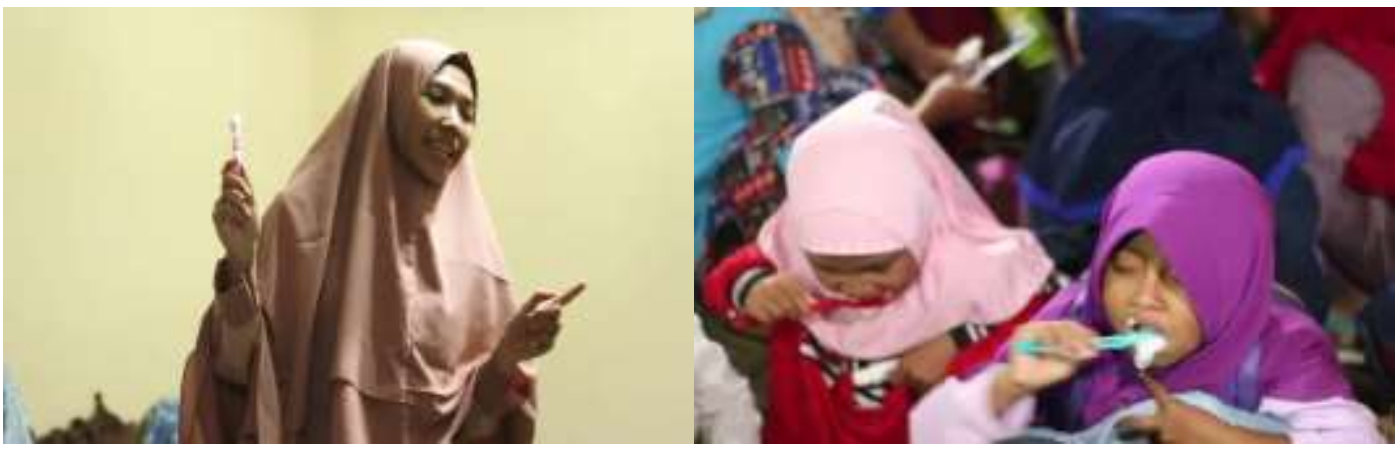

Gambar 3. Penyuluhan tentang cara mencuci tangan dan gosok gigi yang baik dan benar

Penyuluhan dan praktik mencuci tangan dan gosok gigi dengan baik dan benar bersama anak-anak di Desa Kemantren, khususnya di Dusun Alas Kulak. Penyuluhan ini dilakukan dengan metode yang menyenangkan dengan anak-anak, yaitu dengan menonton video, bernyanyi bersama dan memperagakan langkah-langkah cuci tangan dan gosok gigi yang baik dan benar. Pemahamaan dari anak-anak ditindaklanjuti dan diingatkan setiap harinya ketika bimbingan belajar bersama. Hal ini sesuai dengan indikator PHBS Nomor 4 dan 5, yakni untuk cuci tangan menggunakan sabun serta penggunaan air bersih supaya terhindar dari penyakit.



Gambar 4. Penyuluhan kesehatan remaja pada PIK-R SMA Sunan Kali Jaga 
Penyuluhan tentang kesehatan remaja disambut dengan antusias yang besar dari adikadik yang mengikuti organisasi Pusat Informasi dan Konseling Remaja (PIK-R) SMA Sunan Kali Jaga. Materi yang diberikan merupakan permintaan dari adik-adik yang belum pernah diberikan sebelumnya, meliputi Kesehatan Kulit dan Reproduksi, Pertolongan Pertama pada Pingsan, Asma, Gastritis, serta Perawatan Luka. Penyuluhan ini juga disertai sesi tanya jawab dan quiz berhadiah untuk menambah semangat serta menilai pemahaman dari materi yang sudah disampaikan. Selain itu juga dilakukan praktik menggunakan sphygmomanometer yang benar untuk deteksi hipotensi maupun hipertensi sejak dini. Hasil dari penyuluhan dan praktik ini yaitu adik-adik dapat menrapkan ilmu kesehatan dasar yang sudah didapat di UKS, pondok ataupun di lingkungan sekitar untuk diri pribadi, teman-teman dan masyarakat sekitarnya.

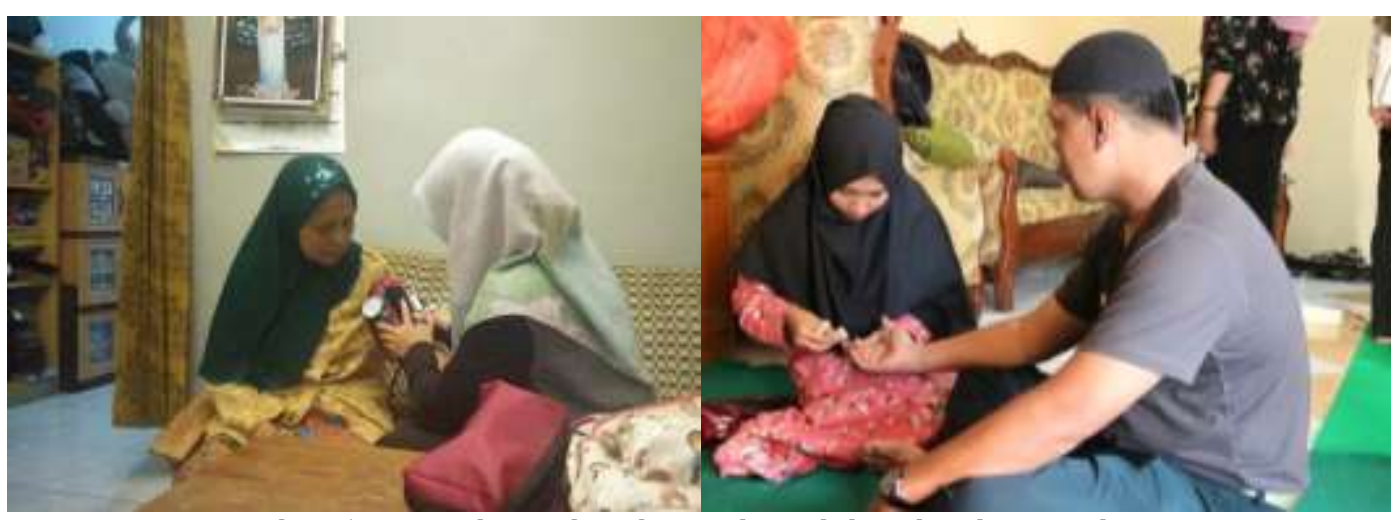

Gambar 5. Pemeriksaan kesehatan dan edukasi hasil pemeriksaan

Skrining kesehatan untuk dewasa lansia meliputi pemeriksaan tekanan darah, gula darah, kolesterol dan asam urat yang dilakukan di posko kesehatan, rumah Ibu Wasiati, dan door to door untuk lansia yang tidak memungkinkan untuk dating ke posko. Setelah itu, dilakukan pemberian Komunikasi Informasi Edukasi (KIE) dari hasil pemeriksaan kesehatan yang telah dilakukan. Warga Desa Kemantren sangat senang dapat mengetahui keadaan tubuhnya melalui hasil pemeriksaan, karena sebelumnya mereka bisa dikatakan tidak pernah atau jarang melakukan pemeriksaan kesehatan. Dari hasil pemeriksaan didapatkan lebih dari separuh jumlah lansia memiliki tekanan darah dan kolesterol yang tinggi. Dengan adanya penyuluhan dan pemeriksaan kesehatan ini, tingkat kesadaran akan kesehatan dan kewaspadaan warga terhadap suatu penyakit menjadi semakin meningkat. Hal tersebut tercermin dari perubahan lifestyle masyarakat menjadi lebih baik, seperti pengurangan konsumsi makanan mengandung garam atau lemak bagi warga dengan hipertensi, pola makan yang lebih baik, mengurangi intensitas rokok, makan makanan yang bergizi, aktivitas fisik teratur dan lain sebagainya. Hal ini sesuai dengan indikator PHBS Nomor 8 sampai 10, yakni untuk mencegah hasil abnormal pada pemeriksaan.

Secara keseluruhan pelaksanaan kegiatan penyuluhan dan pemeriksaan kesehatan ini dapat berjalan dengan lancar, seluruh peserta aktif dan sangat antusias mengikutinya eseluruhan progam. Kegiatan penyuluhan dan pelatihan perilaku hidup bersih dan sehat, serta pemeriksaan kesehatan ini memiliki tujuan untuk meningkatkan pengetahuan dan kesadaran masyarakat akan pentingnya menjaga pola hidup sehat serta kewaspadaan terhadap gejala-gejala awal suatu penyakit. Materi yang diberikan disesuaikan dengan tingkat usia dan pendidikan, dan jenis pelatihan yang dilakukan juga cukup mudah untuk dilakukan mudah dipahami oleh masyarakat, sehingga dapat diterapkan.

\section{KESIMPULAN}

Kegiatan penyuluhan, praktik PHBS, dan pemeriksaan kesehatan guna mewujudkan masyarakat Desa Kemantren peduli terhadap pola hidup bersih dan sehat sudah terlaksana dan dapat diterima dengan baik oleh masyarakat. Masyarakat sangat antusias dengan kegiatan ini. Program seperti ini sangat penting dilakukan, terutama pada masyarakat pedesaan guna 
menyadarkan pentingnya mengupayakan PHBS. Harapannya, penyuluhan dan juga praktik yang disosialisasikan dapat diterapkan dalam kehidupan sehari-hari secara kontinu, serta pemberian edukasi dari hasil pemeriksaan kesehatan dapat menumbuhkan kesadaran akan pentingnya pola hidup sehat dan kewaspadaan terhadap gejala-gejala awal suatu penyakit.

\section{DAFTAR PUSTAKA}

Baker, S., Morawska, A., \& Mitchell, A. (2019). Promoting children's healthy habits through selfregulation via parenting. Clinical child and family psychology review, 22(1), 52-62.

Broyles, S. T., Gollub, E. A., Tohme, A., \& Katzmarzyk, P. T. (2020). Improving Health Behaviors Through Community Engagement: Challenge for a Healthier Louisiana. Health promotion practice, 21(1), 106-113.

Depkes RI. (2002). Panduan manajemen PHBS menuju kabupaten/kota sehat. Jakarta: Departemen Kesehatan.

Fatimawati, I. (2017). Study of clean and healthy life behavior of elementary school students at schools applying Adiwiyata Program at State Elementary School in Prigen Pasuruan. In Proceding $3^{\text {rd }}$ International Nursing Conference (pp.104-110). Jember: Universitas Jember.

Fletcher, G. F., Landolfo, C., Niebauer, J., Ozemek, C., Arena, R., \& Lavie, C. J. (2018). Promoting physical activity and exercise: JACC health promotion series. Journal of the American College of Cardiology, 72(14), 1622-1639.

Jayadipraja, E. A., Prasetya, F., Azlimin, A., \& Mando, W. O. S. Y. (2018). Family clean and healthy living behavior and its determinant factors in the village of Labunia, Regency of Muna, Southeast Sulawesi Province of Indonesia. Public Health of Indonesia, 4(1), 39-45.

Kaddi, S. M. (2014). Strategi penyuluhan kesehatan masyarakat dalam menanggulangi bahaya narkoba di Kabupaten Bone. Academica: Jurnal ilmiah Fakultas Sosial dan Ilmu Politik Universitas Tadulako, 6(1), 1178-1185.

Kemenkes RI. (2011). Pedoman pembinaan perilaku hidup bersih dan sehat. Jakarta: Kementerian Kesehatan.

Kemenkes RI. (2016). Gerakan PHBS sebagai langkah awal menuju peningkatan kualitas kesehatan masyarakat. Jakarta: Kementerian Kesehatan.

Khoiruddin, K., Kirnantoro, K., \& Sutanta, S. (2015). Tingkat pengetahuan berhubungan dengan sikap cuci tangan bersih pakai sabun sebelum dan setelah makan pada siswa SDN Ngebel Tamantirta, Kasihan, Bantul, Yogyakarta. Jurnal Ners dan Kebidanan Indonesia, 3(3), 176180.

König, C., Matt, B., Kortgen, A., Turnbull, A. E., \& Hartog, C. S. (2019). What matters most to sepsis survivors: a qualitative analysis to identify specific health-related quality of life domains. Quality of Life Research, 28(3), 637-647.

Lunenfeld, B., \& Stratton, P. (2013). The clinical consequences of an ageing world and preventive strategies. Best Practice \& Research Clinical Obstetrics \& Gynaecology, 27(5), 643-659.

Park, Y. M., \& Kwan, M. P. (2017). Individual exposure estimates may be erroneous when spatiotemporal variability of air pollution and human mobility are ignored. Health \& place, 43, 85-94.

Ramel, S. E., Brown, L. D., \& Georgieff, M. K. (2014). The impact of neonatal illness on nutritional requirements: one size does not fit all. Current pediatrics reports, 2(4), 248-254.

Saputro, D. P. (2017). Factors affecting clean and healthy life behavior at home of RW 03 Kelurahan Pakunden Blitar City. Jurnal Ners dan Kebidanan, 3(3), 207-212.

Sulistyaningtyas, S., Tamtomo, D., \& Suryani, N. (2016). Pengaruh penyuluhan kesehatan terhadap sikap remaja dalam merawat organ reproduksi. Jurnal Penelitian Humaniora $U N Y, 21(2), 119-128$. 